\title{
Framing Direct Speech: Reporting Clauses in a Contrastive Study
}

\section{Renata Pípalová}

This paper offers a comprehensive contrastive analysis of English and Czech reporting clauses (frames). To that end a corpus was assembled consisting of three Czech, and three English fiction samples, together with their translations. A number of aspects were scrutinized, including the position of the frames, the subjects featured, the word order, type of verbs employed, syntactic patterns displayed, involvement of optional modification, etc. The results seem to suggest, among other things, that analytic English tends to feature explicit subjects, the prosodically more prominent among them causing inversion typically, it frequently displays the crucial SVO pattern, as a rule employs the dicendi verbs, primarily to say, and usually avoids optional syntactic modification. Conversely, Czech, as a synthetic language, gives preference to implicit subjects, exhibits in frames a variety of verbs, both dicendi and other classes, and apart from them, frequently incorporates in frames additional clause constituents. Thus, compared to English, Czech appears to integrate the frames far more smoothly in the narrative, gives a fuller picture of the reported speech situation, encoding more of its elements and in this way it strives to shape more conspicuously the processing of direct speech, taking greater control over the recipient's reception compared to the English original, and simultaneously taking over some interpretative burden from the recipient. Conversely, English appears to treat the frames as more or less automatic, parenthetical units, clearly set off from the narrative, biasing the recipient's processing to a minimum, though inviting much more interpretative and evaluative effort.

\section{Introduction}

In speech we frequently refer to the speech of others, for example, by reporting it, paraphrasing it, reproducing it, representing it, or citing it. Since in such cases language is used to refer to language, it is employed in its metalinguistic function (Šoltys).

"Reporting" (reproduction, etc., hereinafter without inverted commas) of a particular verbal communication in a different situation is based on 
intertextuality (Kristeva), i.e., on the integration of a text in another text, or else on interdiscursivity, whereby we adhere to such rules which are needed for the build-up of various genres, styles, text types or registers. At the same time we may consider it as a conspicuous example of Bachtin's heteroglossia, i.e., dialogue of diverse "voices", discourses, genres, languages, dialects, idiolects, or sociolects, in a literary work.

Instead of reporting (reproduction) of speech, authors may prefer other labels, such as "modes of presentation of character talk or thought" (Leech and Short), "kinds of presenting dialogue and conversation" (Freeborn), "kontextové postupy" (contextual procedures) (Doležel), "constructed dialogue" (Tannen), "represented discourse" (Johanssen) or "podání řeči” (speech representation) (Adam). Adam believes one can only reproduce that speech which has already been realized (e.g., in contrast with what is known as inner speech). This paper employs the, arguably, most wide-spread term of speech reporting for lack of a neutral choice.

The topic of speech reporting is a complex one and far from fully and satisfactorily understood. We may report our own speech as well as somebody else's, we may reproduce speech which was or was not realized, we may cite a portion of speech or writing, we may represent a specific passage or a typically recurring one, and the like. To that end, we can choose from a number of forms, such as direct speech or indirect speech. However, individual forms are not defined and delimited identically, the labels often vary, there are also considerable differences between individual languages and stylistic traditions, and the inventories of forms devised by various researchers differ in range; moreover, the forms are multifunctional, and may enter a myriad of relationships. In addition, since the forms themselves have been coming into existence gradually, one may assume that they may still continue to be doing so.

In the theoretical part of this paper (3. below), attention will be paid to several selected aspects relevant to reported speech. First, the frame will be explored, then, attention will be given to the reported speech itself, following that the boundaries will be discussed and finally the meeting points will be delimited. The analytical part explores one of the prominent language-specific features associated with speech reporting, namely the reporting frames. To that end, a corpus, composed of nearly 6oo frames drawn from Czech and English fiction samples and their translations, will be investigated in a comprehensive way. 


\section{Previous research}

In his classic study O stylu moderní české prózy (On the Style of Czech Modern Prose) Doležel (1960) maintains that in modern fiction the speech of the narrator and that of the characters has been gradually blurred, which is manifested, among other things, in the rise of transition forms of speech reporting. In the Czech linguistic tradition, his terminology has frequently been used to this time. Following other researchers (e.g., Bally, Haller), Doležel distinguishes between direct speech, free direct speech, free indirect speech, indirect speech and mixed speech. (It should be noted that most contemporary Czech authors disregard the lastly mentioned type, as it reproduces only isolated chunks of speech rather than continuous utterances). Doležel's theory is established on several criteria (distinctive markers) as follows: graphic markers (inverted commas), formal markers (verb categories of person and tense), discourse markers (appeal, expressivity and deixis), semantic markers (especially subjective assessment, modality and subjective justifications), and stylistic markers (chiefly the distinctions along the formality scale). Hence, in his framework, free direct speech is defined as failing to satisfy the graphic criteria, and free indirect speech as failing to meet the graphic and formal criteria. (It should be noted that free in this context does not mean frame-less. Rather than that, Doležel distinguishes between two forms of free direct speech, i.e., that with a frame and that devoid of it. Thus free direct speech virtually denotes graphically unmarked direct speech).

In the English linguistic tradition, the theory of reported speech in Style in Fiction by Leech and Short (1981) has been of continuous inspiration to authors. Their framework is established on two parallel scales of speech and thought, varying in degree of intervention, e.g., direct speech, free direct speech, free indirect speech, indirect speech, and the narrative report of the speech act.

Recently, rather than organizing the forms on scales, authors tend to isolate certain distinctive features which may be combined. Such an approach results in matrixes rather than scales. Adam (2006-7) ranks among such authors. His criteria include: type of speech, form of speech and gradient of literal/faithful reporting. Thus, speech may be monological/dialogical, written/spoken, outer/inner, typified, etc. Adam also distinguishes between five forms, i.e., direct speech, free indirect speech, speech provision using the specifically Czech particle prý, indirect speech and the narrative report of speech act (following Leech and Short 1981). Note that free direct speech 
does not feature in this inventory at all. Actually, in Adam's view, each of the forms may be either grafically marked or not (i.e., marked/unmarked), and, moreover, either introduced by a frame or not (i.e., [framed]/free).

Keizer (2009) establishes her matrix chiefly on two criteria, i.e., direct/ indirect on the one hand, and framed/free on the other. She discusses Leech and Short's distinction between speech and thought and concludes that it is appropriate to differentiate between them only from the point of view of narrative techniques, not in terms of their formal properties (847). In her framework she includes a number of transitional forms, some of which are even seemingly contradictory (e.g., framed free indirect speech). The existence of such forms discloses the vague syntactic position of the frame, which is sometimes taken for the main clause (in the initial position), and at other times as an attitudinal adverbial parenthetical structure (in the medial and final positions). She mentions that even more diegetic forms could be identified, but "the question is whether some of these nonprototypical instances are frequent enough and share enough features to justify the creation of a separate category" (864). One can only agree with this standpoint. Corpus linguistics could throw some more light on such issues.

\section{Theoretical part}

\subsection{Frame}

The frame (reporting clause, etc.) is part of the narrator's speech. It is mobile, as it may take the initial, medial or final position. Compared with the reporting clause, the concept of frame is more general, broader and it is delimited on functional grounds (e.g., it may represent only a single clause constituent). At the minimum, the frame specifies the producer of the reported speech. Unlike in the Czech linguistic tradition, in the English secondary sources even the superordinate clause in the indirect speech tends to be considered as a frame.

The syntactic status of the reporting clause is rather indeterminate, indistinct or vague. Some linguists treat it as the main clause with respect to the direct speech it introduces. Quirk et al. give a number of sound reasons in support of such a claim. Conversely, there are also some good reasons which can justify the view that reporting clauses are solely parenthetical adverbial clauses, positionally mobile. Nevertheless, there are also approaches which take the 
initially positioned frames as main clauses and those in the other positions as parenthetical units (Huddleston, Pullum).

A succinct treatment of the topic in the framework of FSP is provided by Červenka:

If we take an utterance composed of an introductory clause and a character's speech as a whole, the first of these parts has a lower degree of communicative dynamism and incorporates the entire utterance into the thematic progression of the narration. The second part, the character's speech, occupies the position of the rheme in relation to the introductory clause. Each of these parts, of course, represents - on a lower hierarchical level - an independent thematic-rhematic nexus. (26)

Furthermore, the usage of reporting clauses in different languages is governed by distinct conventions (e.g., Levý 144), i.e., stylistic and sociocultural conventions. For example, English is marked by a limited variety of these clauses, and particularly the verbs employed in them. By contrast, Czech presses on their stylistic diversification; it employs a much more varied range of the dicendi and sentiendi verbs.

\subsection{Speech}

According to Adam, individual forms are capable of reporting speech with varying degrees of authenticity. Thus even indirect speech, apart from delivering adequately the content of the message, may in differing degrees employ the original language means. Despite that, in Adam's view direct speech is predisposed best to report the speech most faithfully.

That said, however, in non-fiction the interventions into the original speech and its modifications by the reporter are far from scarce. Particularly frequent are modifications and deletions of the features which are usually associated with orality and their replacement, if any at all, by features prone to connote literacy. In this way, authors eliminate various slips of the tongue, fillers, anacoluthons, unintended repetitions, dialectisms, interpersonal means, intonation, stress, half-pronounced words, false starts, contracted verb forms, and others. Such adaptations are witnessed even in the reporting of political speeches or legal proceedings. Significant factors in this context include the conventions adhered to in the particular text type, style, register or genre, in which a part of the original speech is embedded. 
As for fiction, leaving aside the very issue of the "real speech of the character and its reproduction", even there the interventions and modifications are by no means rare and exceptional. For example, from the direct speech portions authors occasionally leave out proper names; dialects tend to be represented selectively, since the readers would probably be overwhelmed by too many dialectisms. Thus, rather than dialects in direct speech we encounter mere illusions of them.

It seems, therefore, that it is apposite to distinguish between the forms and their functions, or else stylistic usage. Direct speech portions featuring in fiction, for instance, are not meant to guarantee authenticity, but solely to suggest it stylistically.

Some authors, however, take this argument much further and claim that authenticity of direct speech is a myth, an illusion, that by definition it may never be attained, irrespective of the text type, genre, style, or register. This follows from a number of reasons, not only from the underrepresentation of the orality features and their possible replacement by their literacy counterparts. More importantly, we should consider the very choice of the speech portion to be reported, or its possible condensation/compression, but particularly the decontextualization of the original speech and its new contextualization, i.e., the interference of voices, or a new construction with a novel purpose, in a new situation, and the like.

However, in contrast to the real faithfulness of the reported speech there are expectations and connotations of the language users in a particular community. Direct speech is generally believed to be the form guaranteeing not only content adequacy, but also formal faithfulness. In this connection one frequently puts into question the responsibility of the authors, e.g., journalists, for the formal and content authenticity, faithfulness of the reported speech (with numerous political, and legal and other consequences).

\subsection{Boundaries}

Direct speech is typically signalled by inverted commas, be it single or double ones, or else by similar graphic means (such as italics, underlining, setting the speech off on a new line or in a narrower column). Nevertheless, these devices represent far more than just graphic means. The punctuation employed marks the boundary unambiguously, it informs us about the upcoming juncture between the narrator's speech and that of the character(s), it may foreground the particular passage or it may indicate a number of other meeting points/ intersections. It should be noted, however, that although punctuation devices 
are naturally inseparable from the written language, these graphic conventions may at least in part be compensated for in speech, for example, by non-verbal means, gestures, change in the voice, dramatizing.

But irrespective of the continuous, blurred boundaries or else conversely, irrespective of the clearly, expressly signalled ones, reported speech may, and often indeed does, appear at the intersection of numerous phenomena, e.g., narrator's speech and character's speech, realized and potential speech, outer and inner speech, at the juncture of orality and literacy, at the crossection of two time lines (most frequently the past and the present), at the interface of several codes (prototypically the standard and a dialect, a sociolect, or another language), at the intersection of two points of view (focalizations), at the juncture of two situations, discourses, etc.

\section{Research}

\subsubsection{Introduction}

The uniquely Czech particle prý has already been given thorough attention (see, e.g., Adam (2006-7), Hoffmannová). This paper looks more closely at another language-specific tendency relating to speech reporting, namely reporting frames (clauses). Several authors (e.g., Levý 144) have already pointed out that in this respect Czech and English display different conventions. This paper strives to offer a comprehensive, contrastive account of the frames employed in Czech and English fiction. I wanted to find out, among other things, whether there was any connection whatsoever between the distinct socio-cultural conventions and the typological differences between the two languages. Moreover, I was interested in the various linguistic and communicative correlates of the two dissimilar socio-cultural conventions.

\subsubsection{Corpus sources}

To that end data were collected from six contemporary works of fiction and their translations. Three of them were originally written in Czech, and three in English. These were as follows:

Klíma, Ivan. Má veselá jitra. Rozmluvy: Praha, 199o. ISBN o9-463-5217-8. (C1) Klíma, Ivan. My Merry Mornings. (Translation by George Theiner). Readers International, Inc.: London, 1993. ISBN o-930523-05-9. (TE1)

McEwan, Ian. Amsterdam. Vintage: London, 1998. ISBN o-o9-928957-1. (E1) 
McEwan, Ian. Amsterdam. (Translation by Markéta Cukrová). Vintage: London, 1999. ISBN o-o9-928957-1. (TG1)

Murdoch, Iris. A Severed Head. Chatto \& Windus: London, 1961. ISBN o-7011-3334-1. (E2)

Murdochová, Iris. Ut'atá hlava. (Translation by Vladimír Kára). Academia: Praha, 2005. ISBN 80-200-1500-8. (TC2)

Škvorecký, Josef. Mirákl. 1972. Atlantis: Brno, 1990. ISBN 80-7108-o19-5. $\left(\mathrm{C}_{2}\right)$

Škvorecký, Josef. The Miracle Game. (Translation Paul Wilson). Lester \& Orpeen Dennys Ltd.: Toronto, 1990. ISBN o-88619-342-7. (TE2)

Tolkien, John Ronald Reuel. The Lord of the Rings, Part 1, The Fellowship of the Ring. 1954. Harper Collins Publishers: London, 2002. ISBN o 00714921 2. $\left(\mathrm{E}_{3}\right)$

Tolkien, John Ronald Reuel. Pán prstenů. Společenstvo prstenů. (Translation by Stanislava Pošustová), 3rd edition. Mladá fronta: Praha, 2001. ISBN 80-204-0925-4. $\left(\mathrm{TC}_{3}\right)$

Viewegh, Michal. Výchova dívek v Čechách. Český spisovatel: Praha, 1994. ISBN 80 -202- 0523-3. ( $\left.\mathrm{C}_{3}\right)$

Viewegh, Michal. Bringing up Girls in Bohemia. (Translation by A.G. Brain).

Readers International, Inc.: London, 1997. ISBN 1-887378-05-7. (TE3)

From each work of fiction, an inner chapter was selected at random and the first 50 instances of reporting frames and their translations in the other language were extracted. It should be noted that due to different delimitations of direct speech in treatments in the two disparate stylistic traditions, account was only taken of the reporting frames accompanying direct speech marked by inverted commas in the originals (irrespective of the marking in their translation counterparts). In the corpus, a number of features were investigated, including presence/absence of translation counterpart; punctuation; position with respect to direct speech; subjects; morphological forms of verbs; dicendi verbs and their translation equivalents; clause patterns; word order in reporting clauses; FSP; socio-cultural considerations.

\subsection{Punctuation/signalling}

Punctuation undoubtedly ranks among language-specific conventions. Unlike in English, in Czech the inverted commas are raised above the line only at the end of direct speech, and not at its onset. Interestingly enough, however, 
one of the Czech originals (C1), somewhat unusually, switched to the English graphic practice instead.

\subsection{Frames without (adequate) matches}

\subsubsection{Reporting frames with no translation counterparts}

Although 150 reporting clauses were selected from the English originals and 150 reporting clauses from the Czech originals, not all of these were necessarily translated in the same manner. In the translations, adequate equivalents were occasionally missing, since some of the frames were turned into regular narrative, whereas others were ellipted altogether. The following tendencies were identified:

Occasionally, all the passage, not just the frame, discussed a language- or cultural- specific phenomenon (e.g., distinction between thou-you), which the translator decided not to translate at all. Two such instances in Czech novels were detected to which there was no translation counterpart provided.

Sometimes the original reporting clause was turned into a regular narrative. The Czech fiction samples enclosed four specimens and an English sample a single instance, all of which were transformed into regular narrative passages in their translations. Significantly, the English translators decided to turn into narrative frames featuring a verb describing a non-verbal action. Occassionally, this transformation went hand-in-hand with looser, less faithful translation. In the following example, in contrast to the Czech original, the author of the English translation adds a semantic feature (waving a hand vs. waving $a$ contemptuous hand).

(1) „Prosím vás!” mávla rukou. (Klíma 9o) - “What do you think!” She waved a contemptuous hand. (Klíma 8o)

Finally, the greatest group, comprising nineteen specimens in all, was constituted by cases where the translation counterpart of the frame was missing. In all instances but one, the originals featured the commonest verbs (to say/rici), and one case employed zeptat se [to ask]. All such frames were of the SVO type, where $\mathrm{O}$ was realized by the direct speech itself. It should be noted that there appeared no modifying element in those frames in the original. The ellipted frames were evenly distributed between the Czech and English translations, as ten frames were extracted from the former, and nine from the latter. 


\section{RENATA PÍPALOVÁ}

Presumably, many of the frames were felt redundant either because of the regular rhythm of the turn-taking in dialogical passages, through which the producer could be reconstructed (2), or because of the stable P-theme paragraphs featuring a single P-theme (see Daneš, Pípalová), i.e., namely the implicated producer of the reported speech $(3,4)$. However, occasionally the two factors were even combined.

(2) "Anyway," said Georgie, "I'd just put the phone down when the door-bell rang [...] Then she suddenly asked me about you."

"Good God," I said, "just like that?"

"Yes," said Georgie. "So I told her." (Murdoch 103) -

„Sotva jsem položila telefon, někdo zvonil [...] Pak se mi zničehonic zeptala na tebe."

„Zatracené!! Tak to tedy bylo."

„Jo, takhle," rekla. (Murdochová 117)

In fact in such female-male dialogues, the Czech reader is also aided by the inflectional endings in the direct speech itself marking the gender, and so the reporting clauses may be felt even more redundant.

(3) Vernon glanced at his watch. He was late for George. He said, Well look, it's quite a thing you're asking me. It needs some thought.' (McEwan 49) -

Vernon pohlédl na hodinky. K Georgeovi prījde strašně pozdě. „Podívej, to je vážná věc. Potrebuji si to promyslet." (McEwan 40 )

(4) "I told her," said Georgie. She sat there gravely, very pale and dignified, one black-stokinged leg curled under her. She adjusted her skirt and, returned my gaze with a face of iron. (Murdoch 103) -

„Já jí to ř rekla." Odpověděla vážně a důstojně, zdálo se mi, že je velice bledá. Fednou nohou v černé punčoše mírně pohupovala. Rukou si urovnala sukni a chladně mi civèla prímo do očí. (Murdochová 116)

It should be noted that (4) illustrates a freeer type of translation. 


\subsubsection{Frames inserted in the translations (with no backing in the original)}

Conversely, the opposite tendency was also witnessed, although only in a limited number of instances. There was a single inserted reporting clause (converted from a regular narrative) in a translation from Czech and four in translations from English. In all of these cases, the original and the translation in fact differed in punctuation (being sometimes set off even in different paragraphs). In this article, reporting frame is not understood to pertain only to such loosely attached structures, although the boundary is admittedly rather continuous.

(5) She added slowly. "It was a relief, all the same." (Murdoch 104) - Pak tiše dodala, „Ale méla jsem radost, že to jsi nejspíš ty.” (Murdochová 118)

\subsection{Overall corpus and subcorpora}

In this way, 300 frames from the two original sets were collected. More specifically, 150 reporting clauses were gathered from the three English original samples, with each contributing 50 frames, and in a similar way, 150 reporting clauses from the three Czech original samples. Given the discrepancies in translations between the originals and their translations, another 139 frames translated into Czech and 136 frames translated into English were gathered. All in all, the whole subcorpus of Czech samples was constituted by 289 items, whereas its English counterpart was composed of 286 specimens. Thus the overall corpus comprised 575 Czech and English reporting frames.

\section{Findings}

\subsection{Position with respect to direct speech}

Reporting clauses may be positioned before the direct speech (initial position, (3) above); inside the direct speech (middle position, (2) above); or after the direct speech (final position, (4) above). In all the corpus (English and Czech sources put together) a clear majority were positioned finally (425 instances, $73.91 \%$ of all), with a relatively even share between the initial ( 78 cases, $13.57 \%$ ) and the middle positions (72 specimens, $12.52 \%$ ). No matter whether the originals or the translations, Czech sources assigned somewhat greater prominence to the final position (75.78\%), compared to the English counterparts $(72.28 \%)$. Conversely, in the English sources, greater preference was given to the initial and middle positions ( $14.39 \%$ and $13.33 \%$ respectively) 
compared to their Czech counterparts ( $12.80 \%$ and $11.42 \%$ respectively). The data turned out to be even more contrastive when considering the originals alone: Czech samples favoured the final position (74.66\%) more conspicuously than did the English samples (71.34\%). All in all, the positions of reporting frames generally exhibited similar trends, although in the Czech data the final position dominated somewhat more pronouncedly.

\subsection{Subjects}

Due to the explored text type (narrative), most of the explicit subjects were realized by proper nouns or personal pronouns. Owing to the typological differences between the two languages, however, a striking difference is obtained in the incidence of personal pronoun subjects. These formed the most numerous group in the English sources (originals and translations combined - 159 instances, i.e., 55.59\%), but were correlated with solely one Czech counterpart, the rest actually displaying no explicit subjects. Czech, being a synthetic language, employed morphological endings to mark subjectverb concord instead. The second most frequent group among the English subjects in reporting clauses, proper nouns (110 specimens, i.e., 38.46\%), found a commensurable counterpart in Czech (102 proper nouns, i.e., 35.29\%). All the other English explicit realizations of fiction subjects turned out to be far less typical (altogether 4.89\%). More specifically, the English samples also contained eleven subjects realized by common nouns, three subjects expressed by indefinite pronouns, and one by a personal pronoun (ř pokaždé ona, Škvorecký 123). In a similar fashion, Czech sources comprised also eleven common nouns, three indefinite pronouns, and one personal pronoun (i.e., altogether 5.19\%). From this it follows that another major discrepancy lies in the proportion of the subjects which were not realized explicitly. In English, the ellipsis of subject was detected only marginally, in three cases in coordinations (i.e., 1.05\%), whereas in Czech an explict subject was missing nearly in two thirds of frames. More accurately, whereas 117 (40.48\%) Czech frames featured an explicit subject, all the others (172, i.e., 59.52\%) did not.

\subsection{Verb morphology}

A decisive proportion of the verbs in frames appeared in their simple past forms, which may be accounted for by the text type investigated (narrative). Naturally, their Czech counterparts also employed past forms. As against the prototype, however, several isolated instances stand out as attention drawing. 
From all the English originals, only two frames with verbs in past continuous were extracted, e.g.,

(6) He was saying (McEwan 52) - ř́ikal právě (McEwan 41)

Furthermore, in translations from Czech, five frames displayed the would + bare infinitive construction to suggest repeated action in the past:

(7) řekla pokaždé ona (Škvorecký 123) - she'd say (Škvorecký 125);

(8) ř́kával jsem po príchodu do hodin (Viewegh 69) - I would say on entering the classroom (Viewegh 70).

It follows that in the translations, many of these forms corresponded to additional adverbials (e.g., právě, pokaždé).

\subsection{Semantic verb classes}

In both of the languages a clear majority of the verbs in frames were undoubtedly verbs of dicendi (e.g., say, declare, ask), and much less frequently of cogitandi (e.g., think), of non-verbal action (e.g., nod) and of paralingual action (e.g., growl).

\subsubsection{Verbs other than dicendi and cogitandi in reporting frames}

It seems that English displays a very limited tolerance for verbs other than dicendi and cogitandi in their reporting clauses. This was especially so when considering the verbs describing the nonverbal or paralingual action. In fact, in all the English fiction samples put together, there were only four such examples. Of these, a single one appeared in the original, and naturally found its Czech equivalent (laugh - zasmát se). The other three were all significantly traced in the translations from Czech (otocit se - spin round; zatukat si na čelo - tap one's forehead; zasmát se - laugh).

In addition to the above specimens, the Czech samples contained another twenty cases of such verbs which were not correlated with similar equivalents. In nine English frames the translator inserted a dicendi verb, particularly the commonest to say, simultaneously transforming the verb suggesting a nonverbal action into a secondary predication, as adverbial of accompanying circumstances: 
(9) Otočil ke mně svi̛j úzký, ptačí obličej (Klíma 92) - he said, turning his narrow, bird's face towards me (Klíma 82).

(10) Chytila měza ruku (Škvorecký 124) - she said, grabbing my arm (Škvorecký 128).

Another solution was to turn the frame into narrative instead (four frames). In one instance, the translation was not provided at all. Conversely, Czech translators from English assigned six original dicendi verbs equivalents suggesting non-verbal action instead:

(11) Clive agreed (McEwan 72) - kývl Clive [nodded] (McEwan 54);

(12) I said to Georgie (Murdoch 101) - otočil jsem se k Georgie [I turned to G] (Murdochová 114).

Thus it seems that whereas the Czech texts welcomed verbs other than dicendi and cogitandi as sources of liveliness and vividity, the English texts tried to keep their number to the minimum.

\subsubsection{Lexical range in original samples}

However, the central verbs employed in the Czech as well as English frames fell into the dicendi group. When exploring the whole lexical range of verbs featured in reporting clauses, one cannot but notice their very restricted diversity in the English originals (E1 twelve verbs, E2 only two verbs (say, ask), $\mathrm{E}_{3}$ eleven verbs), in contrast with their broader range in the Czech originals ( $\mathrm{C}_{1}$ twenty-five verbs, $\mathrm{C}_{2}$ six verbs, $\mathrm{C}_{3}$ twenty-one verbs). The central verbs to say/ríci rríkat will be scrutinized in a special section below. In the meantime, all the other dicendi verbs will be examined.

\subsubsection{Verbs in English frames - lexical range}

Leaving aside for the time being the most common verb to say, a complete list of all the other verbs featuring in the English original samples is provided in the following (less than twenty items altogether): add, agree, answer, ask, be (the response), call, come (the answer), cry, exclaim, growl, laugh, object, repeat, shout, think, wail, whisper. Some appeared up to four times, which shows that the frequency was rather negligible. 
If one compares the list with the verbs featured in the English translations from Czech, one cannot but see a considerable growth in the lexical range, presumably testifying to the influence of the original language and revealing the endeavour of the translators to represent more faithfully the Czech originals. In addition to the verbs laugh, spin round, point, tap (accounted for above), there were approximately twice as many items employed in the translations from Czech: acknowledge, admit, add, agree, announce, ask, assure, calculate, comment, complain, continue, declare, exclaim, explain, go on, hear, implore, instruct, interrupt, interject, invent, lament, order, proclaim, put off, quote, read, read out, reassure, reply, roar, silence, shriek, suggest, tell, want to know. In other words, the differences in the idiolects notwithstanding, there were twice as many different lexical verbs employed in the translations into English compared to the English original fiction samples.

\subsubsection{Verbs in Czech frames - lexical range}

Conversely, leaving aside for the time being the verb ríkat/ríci, if one looks at the sets of verbs employed in the Czech originals, one cannot but notice generally a much greater range of verbs compared to the English originals. All in all, the Czech originals displayed over forty additional verbs which are arranged in alphabetical order as follows: dodat, dotazovat se, doznat, hádat, improvizovat, kriknout, mávnout rukou, naklonit se, nař́kat, nedat se odradit, odvètit, otočit se, oznamovat/oznámit, podivit se, pokračovat, poroučet/poručit, potěšit se, poznamenat, pravit, prohlásit, předčitat, prednášet, predstavit si, prerušit, pripustit, souhlasit, spočitat, ubezpečit, ujistit, ukázat, usadit, uznat, vrátit se, vysvětlit, zajímat se, zahř́mat, zařvat, zasmát se, zatukat, zavř́sknout, zeptat se, žalovat.

In contrast, the translations from English into Czech exhibit a far more limited range of verbs featured in frames (less than twenty items), which roughly corresponds to the number of items employed in the English originals: dodat, kroutit hlavou, kriknout, kývnout, namítat, odvětit, opakovat, ozvat se, pomyslet si, souhlasit, vykriknout, zabědovat, zasmát se, zašeptat, zavrčet, zeptat se, znit (odpovéd), zvolat. Thus, similar to the translations from Czech, even the translations in the opposite direction, i.e., from English to Czech, are apparently influenced by the language of the original.

\subsubsection{Verbs with more translation equivalents}

Although the data included several English, and several Czech, verbs with more translation equivalents in the other language, e.g., ask (zeptat se, kroutit 
hlavou); cry (kriknout, vykriknout); agree (kývnout, souhlasit); oznámit (announce, declare, exclaim, read, tell); ujistit (assure, reassure); pravit (interject, reply, tell); zajimat se (ask, want to know), the two counterpart sets were roughly comparable, since there were approximately twenty verbs in the English originals and in their Czech translations, and roughly forty verbs in the Czech originals and in their English translations. Thus the greatest source of discrepancy undoubtedly lies in the frequency of the commonest verbs to say/ríci/ríkat and their equivalents in the other language.

\subsubsection{Translation equivalents of ríci/říkat}

In the Czech originals, the commonest verb of dicendi, ríci/ríkat (the closest counterpart of to say), featured in fifty-three frames, corresponding to $35.33 \%$ of all. Examining its translation equivalents in English, there were in fact very few: forty-three cases were translated by to say, seven instances were not translated at all, one frame included the verb to reply and one had the verb to point out. (It should be noted that there was another case where the collocation of the verb ř́ci followed by an adverbial prosebně was translated by a single verb to implore). Hence $81.13 \%$ instances of the Czech verb ríkat/ríci were assigned the English counterpart to say. In other words, since the English translators apparently did not mind uniformity, they introduced synonymity rather marginally.

\subsubsection{Translation equivalents of to say}

In contrast, however, as an equivalent of the verb to say, the Czech translators selected its closest counterpart (ríci, ř́kat) only in a third of the frames. More specifically, there were altogether as many as 123 reporting frames in the English originals which featured the verb to say ( $82 \%$ of all). Of these, ríci/ ř́kat appeared as equivalent in forty-one cases, i.e., 33.33\%. The verb to say was translated by groups of lexical counterparts, differing in size from translation to translation, ranging from ten verbs (McEwan), via sixteen units (Tolkien) to twenty-five counterparts (Murdoch). What follows is a list of over forty translation equivalents gathered from all sources arranged in alphabetical order. Naturally, this list does not include cases where to say was inserted in the translations in those frames which in the Czech originals featured verbs suggesting a non-verbal action.

The equivalents include: bránit se, dožadovat se, krìcet, namítnout, neryycházet z úžasu, odmítnout, odpovědět, ohradit se, opáčit, oponovat, oslovit, ospravedlňovat se, otázat se, pozzbuzovat, povzdechnout si, poznamenat, prohlásit, prohodit, pronést, 
pravit, prisvědčit, radit, ř́ci/ríkat, snažit se být roztomilý, soudit, souhlasit, stěžovat si, tázat se, ujistit/ujištovat, upozornit, uvažovat, varovat, vydechnout, vykriknout, vypravit (ze sebe), vzít si slovo, vzlykat, zachraptèt, zajíkat se, zasáhnout, zeptat se, zhodnotit, zoufat si, zvolat. Moreover, additional items could be adduced for collocations (say untruthfully - zalhat [iie]; say quietly - zašeptat [whisper]).

\subsubsection{Semantic classification of the translation equivalents of to say/ríci}

It is naturally very difficult and inevitably simplifying to provide a semantic classification of the set of Czech verbs, serving as translation equivalents of the most common English verb to SAr. However imperfect the following classification may turn out to be, it should at least give in gross terms the range of the aspects by which the commonest verb was semantically enriched. Apart from the central verb of saying, ríci/ríkat, and its near synonyms differing largely in style (pravit, pronést), there are also those which either enhance or play down the importance of what is said (prohlásit; poznamenat, prohodit). Other verbs also evaluate the content of direct speech as representing the producer's point of view (soudit, upozornit, uvažovat, zhodnotit) or assess it in terms of its truth value (zalhat). Many verbs indicate the position of direct speech in conversation, either in a neutral, descriptive way (otázat se, tázat se, zeptat se; odpovédèt), or with some attitudinal overtones (opácít). Several verbs denote the phase of interaction (oslovit, vzit si slovo), occasionally with an attitude (dožadovat se, zasáhnout). Many verbs relate to the attitude of the speaker to the other party's speech, either expressing agreement (prisvédčit, souhlasit); or disagreement, confrontation (bránit se, namítnout, odmítnout, ohradit se, oponovat, ospravedlnovat se). Several equivalents depict the manner of articulation (along with the medium): (kričet, vydechnout, vykriknout, vypravit ze sebe, zašeptat, zvolat). There are also verbs which, apart from the medium, specify also the manner with respect to the noise produced (vzlykat, zachraptèt, zajikat se). Many verbs also convey the emotions of the producer (bédovat, nevycházet z úžasu, povzdechnout si, snažit se být roztomilý, zajektat, zoufat si). Finally, there is a group of verbs characterizing the speech act involved (povzbuzovat, radit, stěžovat si, varovat).

Looking now at the share of the descriptive equivalents of ríci/ríkat/pravit/ pronést in the translations against all the other verbs, we may conclude that out of the 123 instances of to say in the English fiction samples, approximately a half were descriptive (forty-nine were translated by the verb to say, thirteen were given an equivalent describing the interaction (otázat se, tázat se, zeptat se, odpovédět), the remainder, i.e., sixty-two cases, being evaluative/attitudinal, etc. 
Considering now the exact opposite, the semantic reduction of the English translations, it turned out to be rather moderate, presumably because the translators strived to preserve the specificities of the Czech original rather faithfully. Of the many instances of the verb to say in the translations, most (forty-five) corresponded to ríci/ř́kat, eight to pravit, one to odpovědět. In other words, fifty-four cases used to say for descriptive Czech counterparts. In many cases to say was inserted wherever the verb in Czech depicted the non-verbal action. However, there were also nine instances in all, where the Czech verb was evaluative, and the English counterpart was far more neutral. The list includes the Czech verbs depicting the phase in interaction (dokoncit, zakončit); with attitude (pokusit se vyhnout odpovédi); those conveying emotions (bědovat); those suggesting the speech act (stěžovat si, pochválit, dát za př́klad); and verbs expressing disagreement (ohradit se, zdráhat se).

\subsubsection{Analytic and synthetic tendencies in lexis}

In the margin it should be noted that occasionally, the analytic-synthetic dichotomy was also detected at the level of lexis. Naturally, more analytical ways were discovered in the English reporting frames, whether originals or translations: read out loud - predéítat; say untruthfully - zalhat; say quietly zašeptat. However, an example in the opposite direction was also available ríci prosebně - implore.

\subsection{Syntactic patterns in frames}

\subsubsection{Basic pattern SVO without modification}

Exploring now the frequency of the basic pattern of the reporting frames, i.e., subject and transitive verb (e.g., she said), with the object constituted by the reported speech itself, ${ }^{1}$ all in all 110 such cases were detected in the English originals, and sixty-two in translations into English. Conversely, such was the situation in sixty-five Czech originals and in seventy-eight translations into Czech. If these figures are put together, of the 286 English reporting frames collected, 172 (6o.14\% of all) complied with this pattern. In contrast, out of the 289 Czech frames extracted, 143 (49.48\%) corresponded to the pattern. It appears, then, that compared to Czech, English exhibits a more pronounced tendency to employ the basic unmodified frame. However, focussing on the originals alone, the findings turn out to be even more striking and contrastive, with $73.33 \%$ of frames displaying the basic pattern in the English samples, and $43.33 \%$ in the Czech samples. This seems to suggest that English treats the frames mostly as parenthetical, stereotypical units unlike Czech which is 
prone to see them as far more integrated in the prose, with all implications regarding their stylistic diversity.

\subsubsection{Patterns in English samples}

We have seen that the crucial SVO pattern in the reporting frames, where the $\mathrm{O}$ was in fact realized by the direct speech itself, was featured in 110 instances $(73.33 \%)$ in the English original samples in its simplest form, i.e., with no modification. However, the same pattern, though modified usually by an optional adverbial element (such as adjunct of place, time, manner, accompanying circumstances, and the like; e.g., Frank said from where he stood at the urinal [McEwan]; he said at last [McEwan]; said Georgie slowly [Murdoch]), was detected in another thirty-three instances (22\%). This means that the pattern (with or without modification) was exhibited by as many as $95.33 \%$ frames. It follows that the originals enclosed only seven remaining instances $(4.67 \%)$ which belonged to other patterns, e.g., SV (e.g., laughed Frodo [Tolkien]), SVOO (e.g., I said to Georgie [Murdoch]), SVC (e.g., was Vernon's automatic response, his mantra [McEwan]), SVA (e.g., came the answer from far within [Tolkien]) and one verbless case (and then: [McEwan]). The analysis shows that in the English original samples, the above SVO pattern was central, and was largely left unaccompanied by any modifier.

In the translations from Czech to English, however, one notices a remarkable decline in the share of the central unmodified SVO pattern, but simultaneously a clear growth in the proportion of the same pattern with optional modification. More specifically, the translation samples into English included in all sixty-two specimens $(45.59 \%)$ of the SVO pattern in the basic form, and sixty instances (44.12\%) of the same with optional modification (e.g., I replied with some reluctance [Klíma]). In this way, the translations exhibited in all 122 tokens of the pattern. This means that apart from the basic SVO pattern, whether modified or not, corresponding in all to $89.71 \%$ of frames, there were altogether fourteen cases (10.29\%) of other patterns including SV (e.g., she laughed [Viewegh]), SVOO (e.g., Faromir told me during the break [Viewegh]), SVA (e.g., at that moment she spun round [Viewegh]).

To conclude on the two English subcorpora, although even in the translation samples the SVO pattern remained central, there was some decline in its incidence compared to the originals. Moreover, the translation samples turned out to be somewhat more diversified in terms of the clause patterns displayed in their reporting frames, and most prominently, the rate of the optional modifications rose conspicuously. 


\subsubsection{Patterns in Czech samples}

Focussing now on the situation in the Czech originals, the basic unmodified SVO pattern (e.g., rekljsem [Klíma]) was found in sixty-five frames (43.33\%). In addition, the same pattern with optional modification (e.g., řekljsem neochotně [Klíma]) was detected in forty-eight frames (32\%). It follows that apart from the basic SVO pattern, whether modified or not, corresponding in all to $75.33 \%$ of frames, the subcorpus of Czech originals also comprised in all thirty-seven instances $(24.67 \%)$ of frames complying with other clause patterns, including SV (e.g., bèdovala [Klíma]), SVOO (e.g., oznámil jsem jim ztěžka [Viewegh]), SVA (e.g., ukázal na plakáty [Klíma]), SVC (e.g., dělal jsem překvapeného [Klíma]), SVOA (e.g., otočil ke mně svưj úzký, ptači obličej [Klíma]). Of these, the most frequent turned out to be the SVOO pattern (eighteen instances) and the SVA pattern (ten specimens).

Examining now the patterns in the subcorpus of translations into Czech, one notices a clear growth in the proportion of the basic unmodified SVO pattern, as there were in all seventy-eight frames $(56.12 \%)$ of this kind compared to thirty-five specimens (25.18\%) of the same with additional modification. Apart from the basic pattern, with or without modification, which was detected altogether in $81.30 \%$ of the frames in translations from English, the subcorpus included also twenty-six cases (18.70\%) of different patterns in frames, including SV (e.g., kývl Clive [McEwan]), SVOO (e.g., ujištovala ji [Murdochová]), SVA (e.g., nevycházel jsem z úžasu [Murdochová]), SVC (e.g., Antonia se zoufale snažila být roztomilá [Murdochová]) and SVOA (e.g., nakonec ze sebe vypravila ztrnule a velice potichu [Murdochová]). Of these, the most frequent were SV and SVOO (nine instances each).

To conclude on the two Czech subcorpora, it seems that although even in the original subcorpus the SVO pattern turned out to be central, there was a remarkable growth in its share in the translation samples. Moreover, in terms of the clause patterns displayed in the reporting frames, the original sources appeared somewhat more diversified, and most prominently, they exhibited many more cases of the optional modifications.

\subsubsection{Additional syntactic modifications and complementations in translations}

As for the syntactic modifications in the translations, more cases of additional, largely optional syntactic elements appeared in the Czech frames than in their English counterparts. Considering the Czech translations from English, there were ten objects, thirteen adverbials and a single attribute in addition 
to the originals. This means that in general, the translations into Czech were communicatively richer than their originals, the difference being in twenty-four reporting frames (over a sixth of all).

(13) said others (Tolkien 88) - oponovali jim druzí (Tolkien 68)

(14) I said (Murdoch 108) - pozzbuzoval jsem ji (Murdochová 122)

(15) said Georgie (Murdoch 104) - prohlásila vzdorně Georgie (Murdochová 118)

(16) said Georgie (Murdoch 106) - zeptala se po chvilce (Murdochová 120)

(17) was Vernon's automatic response, his mantra. (McEwan 52) - zněla Vernonova automatická odpověd', jeho věčná mantra. (McEwan 41)

Conversely, looking at the English translations from Czech, they too, were occasionally enriched by additional syntactic elements, though prototypically by dicendi verbs (twelve cases), and only scarcely by other clause elements (three adverbials, an attribute and an object). This means that in English the willingness to enrich the translation was limited and rather patterned.

(18) he said, ending the lecture (Škvorecký 138) - zakončil přednášku (Škvorecký 133)

(19) he continued, pointing to the posters (Klíma 84) - ukázal na plakáty (Klíma 93)

(20) he asked me immediately (Viewegh 76) - dotazoval se hned (Viewegh 44)

(21) she said, with artful disappointment in her voice (Škvorecký 128) - řekla zklamaně (Škvorecký 123)

The typical enrichment of English frames (i.e., dicendi verbs) only suggests a strong tendency to reinforce the stereotype in English, i.e., to employ a dicendi verb in the frame. Simultaneously, it complies with English as an analytic language, and presumably also discloses the status of reporting frames which are prone to be treated more or less as automatic, stereotypical phrases. 
Somewhat more prominently, however, we also see the reverse tendency, where the English translations dispense with twelve clause elements, for instance:

(22) she explained (Klíma 81) - vysvětlila mi (Klíma 9o)

(23) I declared laboriously (Viewegh 68) - oznámil jsem jim ztěžka (Viewegh 68)

(24) she asked (Škvorecký 134) - zeptala se skoro upjatě (Škvorecký 129)

(25) I admitted (Klíma 86) - pripustil jsem neochotně (Klíma 96)

Thus, it is possible to conclude that the Czech frames analysed appear communicatively somewhat richer, which was achieved, among other things, by a greater share of additional syntactic modifications (and complementations).

\subsection{Word order and FSP}

\subsubsection{Inversion}

Of all the 286 English frames, 73 displayed inversion, which accounts for $25.70 \%$. In contrast, of all the 289 Czech frames, 108 exhibited inversion, which amounts to $37.37 \%$. Not surprisingly, then, inversion in reporting frames is generally more frequent in synthetic Czech with largely free word order than in analytic English.

In fact, Czech employs inversion only with explicit subjects, which, needless to say, must be communicatively significant to be expressed at all. More specifically, Czech resorts to inversion usually with subjects realized by proper nouns, common nouns and indefinite pronouns. Thus, for the sake of greater comparability of data, attention was narrowed to their counteparts in English. Of all the 117 frames exhibiting such explicit subjects in Czech, 108 (including the one featuring the only personal pronoun subject), i.e., $92.31 \%$ of all, displayed inversion. The same classes of subjects were found in 123 English frames. Of these, inversion concerned 73 instances, i.e., 59.35\%.

It follows that within this group, inversion turned out to be almost a regular practice in Czech, since it was traced nearly in all the cases where an explicit subject was used. More specifically, it was detected in all the instances where the frame was positioned medially and in all instances but one positioned 
finally. ${ }^{2}$ In contrast, none of the nine initially positioned frames with explicit subjects was inverted.

In the English data, inversion accompanied almost exclusively nominal subjects (i.e., $97.26 \%$ of all, with two additional specimens where subjects were realized by indefinite pronouns). Like in Czech, in English there was not a single instance of inversion with initially placed frames (even though such cases are not precluded). ${ }^{3}$ Of all the 94 finally placed frames featuring nominal subjects, 63 (i.e., 67.02\%) lent themselves to inversion. Similarly, of all the fourteen medially positioned counterparts, ten (71.43\%) were susceptible to inversion. Thus, although the rates of probability for inversion in both the positions turned out to be commensurable (around 70\%), inversion in the final position convincingly outnumbered that in the medial position, covering $86.30 \%$ of all cases.

\subsubsection{Inversion and FSP factors}

Even though generally lower compared to Czech, the rate of inversion detected in analytic English is striking, given the fixedness of English word order. Clearly, it testifies to the author's special communicative needs. Since in analytic English, word order has chiefly a grammatical function and asserts itself as a means of FSP only in a limited way, one may rather presuppose that inversion results from an interplay of several FSP factors (semantic, contextual and/or prosodic). These factors are given some attention in what follows:

In addition to the position of the frame and the word class of the subject (nominal ones are unambiguously favoured, for they are usually prosodically rather heavy), there are other factors affecting inversion in English. It is facilitated, among others, by the stereotypical verb to say, due to which attention is shifted to the subject itself and in line with FSP findings, this slight foregrounding of subject is reflected in its positioning. Of the 73 cases of inversion detected in English, 65 instances (89.04\%) included the basic verb to say in the frame. It follows that due to the semantic factor, more attentiondrawing verbs are not very likely to cause inversion. Further, inversion seems more common with minimal frames (i.e., those devoid of any complementation and modification). Of the 73 inverted frames, 54 (73.97\%) complied with this tendency and contained solely subjects and transitive verbs. (Compare: said Agata (Viewegh 73) vs. Guy said politely (Viewegh 73); unlike the former, communicatively oriented towards the producer, the latter case is oriented away from the producer to the post-verbal specification). In this context 
it is worth recalling that this study scrutinizes a fiction corpus, where the proportion of non-minimal frames was not negligible, as authors occasionally found it necessary to incorporate additional particularizations of the scene (e.g., recipient, time, manner of speech, or circumstances) in their frames. Furthermore, the verb itself should appear in simple past (or simple present) form. In fact, this was the case of all the verbs in question (in contrast with the uninverted instances, e.g., Tanya would not be put off (Klíma 86), with prosodically heavy verb forms).

Another factor entering the interplay is the contextual factor. It is significant whether the producer of direct speech is already established on the scene of discourse (context-bound) or not, which may be, among others, corroborated by the very choice of the lexical verb - semantic factor). The following passages should illustrate:

(26) "Write it off, what else?" said the staff nurse. "Mr Klíma, you've no idea [...] before you started working here," the staff nurse continued. (Klíma 80)

It should be noted, however, that in fiction a limited number of characters are usually established on the scene, so their novelty is relative and a matter of degree.

Moreover, fiction includes many dialogical passages with regular producer shifting in turntaking. Inverted frames slightly foreground the particular producers and treat them somewhat contrastively (27), whereas non-inverted ones may be more suggestive of collaborative floor (28); frequently, such frames also resemble neutral, backgrounded, appended tags. Tellingly, the first passage below is a dialogue, whereas the second a multilogue among peers:

(27) "Ah, you mustn't feel any guilt!" said Antonia.

"You misunderstand me," said Georgie. (Murdoch 109)

(28) "Vladya," I implored him, "save me."

To crown it all, I began to feel that a hornet had stung me in the tongue on my way to school.

"I'll never touch another drop," I declared laboriously.

"Don't blaspheme," Vladimir said.

He gently bent my head backwards and put a drop of something in each of my eyes. It stung.

"It gets better," Jaromir said. 
"The artist has to drink," Vladimir commented, "because he sees more deeply than other people." (Viewegh 68)

Moreover, it seems that occasionally even the distance between the turns matters, as turns separated by longer passages of author's comments frequently weakened the contrastive effect due to which inversion in the frames was less likely (e.g., McEwan).

This paper investigates solely fiction samples. ${ }^{4}$ It should be noted that some original sources used inversion consistently (Tolkien, Murdoch), while others defied it, in line with the rather fixed word order in English (McEwan). As for the translations from Czech, they were all inconsistent in this respect. Apparently, apart from the tendencies and the common practice in a particular genre, style or register, inversion primarily serves the authors's specific communicative needs and is at least in part also a matter of his/her idiolect and personal taste. In other words, it also reflects the authors's attitude to the frames (e.g., taking them for purely formulaic, mechanic, stereotypical units or not quite so; the latter brings in the frames diversity of various kinds and degrees (lexical, syntactic, word order - presumably showing among others, the author's openness and sensitivity to the effect of the diverse factors of FSP).

\subsubsection{Concluding remarks on reporting and FSP}

From the viewpoint of FSP, there are two distributional fields (Firbas 15), one embodied by the reporting clause, and the other by the loosely embedded direct speech. Whatever the position of the former, it takes the thematic function, with the latter fulfilling its rhematic counterpart.

Within the distributional field of the reporting frame, in English, the grammatical principle asserts itself rather strongly, and allows only for a relatively limited incidence of inversion. Furthermore, the frames are usually brief and stereotypical, which assigns them almost formulaic character and invites their rather mechanical treatment. So, whenever employed, inversion is a means of foregrounding. It renders the item identifying the producer prosodically more salient, conspicuous, and even when contextually bound, somewhat contrasted.

In contrast, in Czech, word order is the leading principle of FSP. Therefore, inversion affects an overwhelming majority of frames with explicit subjects, appearing in medial and final positions. With the prevalent Czech frame being devoid of explicit subject, however, even the rhytmical principle may be among the reasons for additional syntactic expansions of Czech frames. 
Moreover, exploring the higher order unit, i.e., whole sentence, Czech samples employ a lexically variegated set of verbs, which are naturally more attention drawing compared to their to SAY counterparts. Moreover, they appear semantically and syntactically somewhat richer, pushing the communication more forward compared to their English equivalents. Therefore, in the higher order communicative field (CF-1, see, e.g., Svoboda 79) the distribution of CD (communicative dynamism, see Firbas) across both direct speech and the reporting clause (frame) seems far more gradual compared to English, and the junctions between these two communicative fields seem much smoother.

\subsection{Socio-cultural considerations}

In addition to the foregoing, it seems that the Czech tradition calls for more conspicuous guidance, and the author takes greater control over the recipient's reception compared to the English original, simultaneously taking over some interpretative burden from the recipient.

\section{Conclusion}

The above analysis seems to suggest that concerning the reporting frames, the two languages share a number of features. For example, both assign the frame the same main function, i.e., treating it as part of the author's narrative explicitly introducing the original verbal communication, chiefly its producer, both tend to position their reporting frames finally, both prioritize in their frames verbs of dicendi, and both preferably employ in them the SVO pattern.

However, the two languages also differ in many respects, although a considerable proportion of these differences is a matter of degree and tendencies rather than sharp contrasts. Among the more prominent distinctions rank those related to typological characteristics. English, being an analytic language, clearly tends to express the subjects explicitly, whereas Czech, as a synthetic language, in the majority of instances (around 6o\%) does not. Czech is much more likely to feature inversion in frames, which is nearly a regular practice wherever the subject is explicit and appears outside the initial position. In English, inversion is rather common especially with nominal subjects in non-initial positions. English scarcely involves in frames verbs other than dicendi (cogitandi), while Czech welcomes other groups as well. Occasionally, English resorts to analytical solutions when searching for 
lexical equivalents of some of the rarer Czech verbs. In translations, English translators usually insert the commonest verb to say, relegating the other types of verbs (e.g., suggesting non-verbal or paralingual action) to the non-finite clause, as adjuncts of accompanying circumstances.

As for the overall situation of frames in English, they tend to be slightly more positionally mobile, and as a rule feature explicit subjects (the prosodically heavier ones, especially nominal ones, among them being likely to cause inversion). They are very reluctant to display verbs of non-verbal or paralingual action. The verbs are prone to be used in past simple and the pattern typically corresponds to SVO, and is left unmodified. Furthermore, with the communicatively rather empty frames, attention is unambiguously drawn to the direct speech itself. Due to these characteristics, English appears to treat the frames more or less as automatic, stereotypical parenthetical units, clearly set off from the narrative, whose most conspicuous function in a communicative framework is solely to identify/disambiguate the producer of direct speech.

In contrast, Czech prioritizes the final position somewhat more frequently, many of its subjects are only implicit, inversion being a regular practice with most explicit subjects but for those positioned initially (only one instance was detected in an original sample). The set of verbs employed in its frames is variegated, featuring mainly the prominent verbs of dicendi and less typically, though not exceptionally, verbs expressing the non-verbal or paralingual action. The verbs appear in their past forms, and the pattern tends to be SVO, but is frequently modified. Furthermore, with the communicatively rather rich frames, attention is somewhat more evenly divided between the reporting clause and the direct speech itself. In this way Czech definitely displays a tendency to treat these structures as an integral part of the narrative in which they are organically interwoven.

The translations in fact corroborated the above tendencies, as similar trends could be traced in the translations in both directions. Generally speaking, there were more instances with analyticity in the structure and lexis in the English translations compared to the Czech ones. English translations occasionally reduced the originals semantically, dispensing with some meaning aspects of the verbs or else with some syntactic elements. In this way the translators into English strived to keep the intervention into the reception to the minimum, employing frequently the central verbs of dicendi and occasionally dispensing with some of the optional syntactic modification. Conversely, compared to the originals, Czech translations appeared much richer in the semantic aspects of 
the verbs selected and occasionally incorporated additional syntactic elements in frames. Thus the translators into Czech were more focussed on disrupting what they saw as monotony and achieved conspicuous lexical diversity in their translation equivalents of the verb to say, compared to other verbs.

Thus it seems that in Czech, the distribution of CD across both, direct speech and the reporting clause (frame) seems far more gradual and smoother, compared to English. This presumably indicates that in Czech, the boundary between the frame and the direct speech is somewhat less sharp compared to English, due to which the frame is felt to be far more integrated in the narrative.

To conclude, we have seen that frames are rather significant. Not only has their presence syntactic consequences, but chiefly communicative and interpretational ones. Actually, in line with his or her communicative intention the reporter chooses and encodes in them some of the elements and factors of the reported speech situation, especially the particular speaker, but in addition to that, possibly also the addressee, manner of speech, time, circumstances, and others. We have seen that in the English frames, as a rule, only the producer of the speech is particularized, and the verb employed tends to be one of the dicendi group, prototypically the commonest to say. In contrast, in Czech frames, a generally fuller and more accurate depiction of the reported speech event is provided compared to English, as Czech tends to encode and specify a range of additional features of the reported event. Frequently, Czech also specifies the recipient, the manner of speech, the setting/circumstances of speech, the speech act, etc. This is partly done using additional syntactic constituents, chiefly optional modification, and partly using a whole range of verbs both of the dicendi group and others (of cogitandi, non-verbal and paralingual action) which particularize a range of various aspects, such as noise, emotional load, phase of interaction, or medium.

However, since the report is also carried out with respect to the addressee, we may assess the frames in terms of their degrees of cooperativeness. Among other things, we may examine how the cooperative maxims are adhered to, namely those of manner and quality, how difficult the forms are for the addressee to decode, and how they manipulate or facilitate the reception of the report. In this respect it seems that since there is usually no other participant identified through the frame but the producer of direct speech, and since the verb displayed tends to be the commonest to say, presumably in order not to shape the interpretation in any specific way, not to interfere in the reception 
and not to bias the recipient in one way or another, the authors in English deliberately leave unnoticed many elements of the reported speech situation and do not encode them in the frame. This activates the recipient and calls for more interpretative and evaluative effort. Thus in English, the demands Czech makes on stylistic richness and diversity, are somewhat backgrounded in an attempt to give an impartial account.

Conversely, it seems that the Czech tradition calls for greater stylistic diversification of verbs, along with a fuller account of the original speech situation encoding more elements in the basic pattern primarily as optional modification. This all results, among other things, in more conspicuous guidance, and the author takes greater control over the recipient's reception compared to the English original, simultaneously taking over some interpretative burden from the recipient. In this way, the frames appear to condition the reception in a specific way, and along with that, they also reduce and constrain the interpretative and evaluative role of the recipient. Hence the Czech authors appear to control the reception of direct speech far more carefully than their English counterparts.

Simultaneously it is possible to examine the forms in relationships to their effect on the recipient. It appears that English report tends to be introduced merely as fact, whereas Czech, by using more foregrounded forms, featuring diverse rarer verbs, including those charged with emotions, engages the recipient more in the act of processing so that he or she may live through the communication.

Furthermore, reporting clauses (together with direct speech and the related forms of reported speech) are phenomena taking part in interdiscursivity, and thus it is vital to take account of diverse stylistic and sociocultural factors and to assess them also in relation to the tendencies in the respective text type, style, register, or genre. Naturally, I explored solely a limited corpus, moreover composed of fiction samples exclusively. It would be interesting to research a more extensive fiction corpus and particularly, to compare the findings with those based on other text types.

Last but not least, the language-specific tendencies and the common practice in a particular text-type, genre, style or register notwithstanding, the frame primarily serves the author's particular communicative need and is at least in part also a matter of his/her idiolect and personal taste. Thus it also reflects the authors's attitude to the frames (e.g., taking them for purely formulaic, mechanic, stereotypical units or not quite so; the latter brings in the 
frames diversity of various kinds and degrees (for example, lexical, syntactic, or word order - which may disclose, among others, also the author's openness and sensitivity to the effect of the various factors of FSP).

\section{Notes}

1. It should be noted, however, that occassionally the object complementation of the transitive dicendi verb is provided in the reporting frame itself, although in the majority of cases the object is missing and is constituted by the direct speech.

Compare: SVO vs. SV[O] - he praised her as she merited (Viewegh) vs. I asked $O$ (Škvorecký).

This only confirms the syntactically fuzzy and indistinct status of the reporting frames. However, due to the multiclass membership of certain verbs, some verbs are acceptable without objects, but may be used with them as well (e.g., he agreed).

2. The only finally positioned uninverted Czech frame was heavily expanded. Surprisingly enough, its English original was inverted. This apparently illustrates a free translation from English:

"Don't dislike me, Georgie," said Antonia. She bent her appealing look upon Georgie [...] (Murdoch 109)

"Vy mé asi nemáte moc v lásce, vidte," Antonia se zoufale snažila být roztomilá [...] (Murdochová 123)

3. Although the data explored displayed no instances of $\mathrm{S}-\mathrm{V}$ inversion in frames appearing in initial positions, such cases are sometimes detected in news reports:

'Says Murray: "It was in my room with a pal and after several drinks I started doing conjuring tricks."' (Biber et al., 922.)

4. For example, Biber at al. compare inversion rates in journalism and fiction.
Abbreviations and symbols
C1-3: $\quad$ Czech original samples 1-3
CD: $\quad$ communicative dynamism
E1-3: $\quad$ English original samples 1-3
FSP: Functional Sentence Perspective
SV: $\quad$ subject-verb pattern
SVA: $\quad$ subject-verb-adjunct pattern
SVO: $\quad$ subject-verb-object pattern 
SVC: $\quad$ subject-verb-(subject) complement pattern

SVOA: subject-verb-object-adjunct pattern

SVOO: subject-verb-object-object pattern

SVOC: subject-verb-object-(object) complement pattern

TC1-3: Translation samples into Czech 1-3

TE1-3: Translation samples into English 1-3

\section{Works Cited}

Primary sources

Klíma, Ivan. Má veselá jitra. Praha: Rozmluvy, 1990.

---. My Merry Mornings. (Translation by George Theiner). London: Readers International, Inc., 1993.

McEwan, Ian. Amsterdam. London: Vintage, 1998.

--- Amsterdam. (Translation by Markéta Cukrová). Praha: Volvox Globator, 1999.

Murdoch, Iris. A Severed Head. London: Chatto \& Windus, 1961.

Murdochová, Iris. Ut'atá hlava. (Translation by Vladimír Kára). Praha: Academia, 2005.

Škvorecký, Josef. Mirákl. 1972. Brno: Atlantis, 1990.

---. The Miracle Game. (Translation Paul Wilson). Toronto: Lester \& Orpeen Dennys Ltd., 1990.

Tolkien, John Ronald Reuel. The Lord of the Rings, Part 1, The Fellowship of the Ring. 1954. London: Harper Collins Publishers, 2002.

---. Pán prstenů. Společenstvo prstenů. (Translation by Stanislava Pošustová), 3rd edition. Praha: Mladá fronta, 2001.

Viewegh, Michal. Výchova dívek v Čechách. Praha: Český spisovatel, 1994.

--. Bringing up Girls in Bohemia. (Translation by A.G. Brain). London: Readers International, Inc., 1997.

Secondary sources

Adam, Robert. "Formy podání řeči." Slovo a slovesnost. 64, 2, 2003: 119-128.

---. "Stručné dějiny a současná situace výzkumu podání řeči." Slovo a slovesnost. 64, 2, 2003: 128-132.

---. "Řeč postav ve vyprávění." Česká jazyk a literatura. 57, 4, 2006-7: 174-180.

Bachtin, Michail Michajlovič. Román jako dialog. Praha: Odeon, 1980.

Bečka, Josef Václav. Česká stylistika. Praha: Academia, 1992.

Biber, Douglas et al. Longman Grammar of Spoken and Written English. Harlow:

Pearson Education Ltd. 1999. 
Chafe, Wallace. Discourse, Consciousness and Time. The Flow and Displacement of Conscious Experience in Speaking and Writing. Chicago: The University of Chicago Press, 1994 .

Coulmas, Florian, ed. Direct and Indirect Speech. Berlin: Mouton de Gruyter, 1986.

Čechová, Marie et al. Současná stylistika. Praha: Nakladatelství LN, 2008.

Červenka, Miroslav. "Narration and Description from the Standpoint of Functional Sentence Perspective." The Structure of the Literary Process. Eds. Peter Steiner, et al. Amsterdam/Philadelphia: John Benjamins Publishing Co., 1982: 15-44

---. Obléhání zevnitř. Praha: Torst, 1996.

Daneš, František et al., eds. Mluvnice češtiny III, Skladba. Praha: Academia, 1987.

Daneš, František. "Paragraph - A Central Unit of the Thematic and Compositional Build-up of Texts." Eds. Brita Warwik, Sanna-Kaisa Tanskanen and Risto Hiltunen. Organization in Discourse. Proceedings from the Turku Conference. Turku: University of Turku, 1995: 29-40.

Doležel, Lubomír. O stylu moderní české prózy. Praha: Nakladatelství ČSAV, 1960.

Dušková, Libuše et al. Mluvnice současné angličtiny na pozadí češtiny. Praha: Academia, 1994.

Firbas, Jan. Functional Sentence Perspective in Written and Spoken Communication. Cambridge: Cambridge University Press, 1992.

Fludernik, Monika. The Fictions of Language and the Languages of Fiction. The Linguistic Representation of Speech and Consciousness. London: Routledge, 1993 .

Freeborn, Dennis. Style. Text Analysis and Linguistic Criticism. $2^{\text {nd }}$ edition. London: Macmillan Press Ltd. 1996.

Greenbaum, Sidney and Randolph Quirk. A Student's Grammar of the English Language. Harlow: Longman, 1990.

Hoffmannová, Jana. "Intertextualita v mluvených projevech. Úvahy o metodologii výzkumu a konceptuální soustavě.” Stylistika. 11, 2002: 371381.

---. "The Reproduction of One's Own Speech or the Speech of Others: from L. Doležel to Contemporary Communication and Corpus Research." Tradition versus Modernity. From the Classic Period of the Prague School to Translation Studies at the Beginning of the 21st Century. Eds. Jana Králová et al. Praha: FFUK, 2008. 101-123. 
Hrbáček, Josef. Nárys textové syntaxe spisovné češtiny. Praha: Trizonia, 1994. Huddleston, Rodney and Geoffrey Pullum. The Cambridge Grammar of the English Language. Cambridge: Cambridge University Press, 2002.

Johansen, Marianne. "Agency and Responsibility in Reported Speech." Journal of Pragmatics. 43, 2011: 2845-286o.

Johanssen, Marjut. "Sequential Positioning of Represented Discourse in Institutional Media Interaction." Eds. Anita Fetzer and Christiane Meierkord Rethinking Sequentiality: Linguistics Meets Conversational Interaction. Pragmatics and Beyond. Amsterdam: John Benjamins Publishing Company, 2002. 249-272.

Karlík, Petr et al., eds. Př́ruční mluvnice češtiny. Praha: Nakladatelství Lidové noviny, 1995 .

Keizer, Evelien. "The Interpersonal Level in English: Reported Speech." Linguistics. 47, 4, 2009: 845-866.

Kristeva, Julia. Slovo, dialog a román. Texty o sémiotice. Praha: Sofis, 1999.

Leech, Geoffrey N. and Michael H. Short. Style in Fiction. Harlow: Longman, 1981.

Levý, Jiří. Umění překladu. 1963. Praha: Ivo Železný, 1998.

Patáková, Marta. "Atypické funkcie podoby priamej reči v umeleckej próze." Slovenská reč. 43, 6, 1978: 342-352.

Pípalová, Renata. Thematic Organization of Paragraphs and Higher Text Units.

Praha: Univerzita Karlova v Praze, Pedagogická fakulta, 2008.

Quirk, Randolph et al. A Comprehensive Grammar of the English Language. Harlow: Longman Group Ltd., 1985.

Slembrouck, Stef. "The Parliamentary Hansard Verbatim Report: the Written Construction of Spoken Discourse." Language and Literature. 1/2,1992: 101-119.

Svoboda, Aleš. "The Hierarchy of Communicative Units and Fields as Illustrated by English Attributive Constructions." Brno Studies in English. 7, 1968: 49-85.

Šoltys, Otakar. Verba dicendi a metajazyková informace. Praha: ČSAV, 1983. Tannen, Deborah. Talking voices. Repetition, Dialogue, and Imagery in Conversational Discourse. Cambridge: Cambridge University Press, 1989. Toolan, Michael. "The Significations of Representing Dialect in Writing." Language and Literature. 1/1, 1992: 29-46. 